\title{
Knowledge Production in Higher Education: Policies and Practices in Nigeria
}

\author{
Charles M. Ogbodo ${ }^{1}$, Sunday I. Efanga ${ }^{1} \&$ Usen G. Ikpe ${ }^{1}$ \\ ${ }^{1}$ Department of Curriculum Studies, Educational Management and Planning, University of Uyo, Uyo, Nigeria \\ Correspondence: Sunday Inyang Efanga, Department of Curriculum Studies, Educational Management and \\ Planning, University Of Uyo, Akwa Ibom State, Nigeria. E-mail: drefanga200@gmail.com
}

\author{
Received: October 8, 2013 Accepted: November 14, 2013 Online Published: November 19, 2013 \\ doi:10.5539/ies.v6n12p9 URL: http://dx.doi.org/10.5539/ies.v6n12p9
}

\begin{abstract}
This paper presents a discussion on knowledge production in higher education, policies and practices in Nigeria. At the introduction, the overall objectives of higher education are highlighted and the concepts of policies explained. The paper therefore identifies some factors as the major challenges to knowledge production; some of the factors are lecturers or research fellows, money, governance and public policy support. It is the belief of the authors that these inputs should be deployed in adequate proportions both in quality and quantity as no knowledge produced can rise above the quality of those who produce it. Some recommendations made include that government should allocate adequate funds to higher education to enable her improve the quality of her teaching and research in line with international standards. Nigeria should have working policies guiding higher education which are monitored and evaluated annually.
\end{abstract}

Keywords: knowledge, knowledge production, higher education, policy and practice

\section{Introduction}

Knowledge is the most significant variable in the equation of economic development in the $21^{\text {st }}$ century. Knowledge as a product has many facets. To know or have knowledge of something would definitely involve learning or some finding out which implies research. This something that is known or is found out can have value in the sense of having utility. It can yield satisfaction when properly utilized and can also yield economic returns when invested. Knowledge as know-how involves having practical knowledge of how to do something as in subduing ones environment, exploiting natural resource and adding value to them by processing them. Since knowledge is a product, it can be produced and production involves the input of certain factors as in this case -personnel, ideas, money and managerial acumen or ability. This paper is based on the Agency theory which examines the relationships between the agency and the principal. The agency in this case is the higher education institutions while the principal is the state. The Agency theory sees information as a product just as this concept paper views knowledge (information) as a product of higher education that should yield satisfaction to the principal.

Higher education everywhere is in the business of knowledge production. It plays a significant role in balancing environmental, societal and economic development as well as improves quality of life. Ogbodo (2013) stressed that it is in higher education that we have the highest concentration of specialized knowledge personnel with the right mix of ideas that can be processed with appropriate material and of monetary inputs to produce knowledge that would continue to advance the course of human progress. It must be noted however that higher education is also associated with asymmetric information including imperfect quality information (Dill \& Soo, 2004; Stiglitz, 2000). If knowledge is produced and it has no value, it is useless. It is the application of knowledge that distinguishes a knowledgeable person from a wise person, a developed nation from undeveloped nation. Knowledge production for its own sake is therefore not enough. Higher education must therefore produce knowledge that is problem specific, custom produced as it were to address our peculiar problems and circumstances.

As a nation, we cannot afford the luxury of deploying resources to just be recycling and distributing existing or extant knowledge. We cannot afford to think in terms of analogous in the digital world. We must ask the question "why" before the "what", when it comes to knowledge production. 
In this paper therefore we focus at higher education in Nigeria as an industry that produces knowledge and see how it does so based on the views of knowledge and its relevance as already presented. We also examine the existing policies and practices in higher education and see how they foster or hinder real knowledge production and it utilization in Nigeria. The paper would also examine what appropriate policies and practices can be put in place to ensure that Nigeria as a nation is knowledge driven.

\section{Higher Education Policy in Nigeria with Regard to Knowledge Production}

Policy is said to be a pattern of purposive action by which political institutions shape society (Ashford, 1981). It typically involves a wide variety of efforts to address certain societal problems. Policy has direct relationship with politics. According to Ikotuno (2003) policies are shaped primarily by the manner in which power is organized within each country. What is evident here, is that policy is government programme of action. It encompasses values, which set priorities and roles within government and society. It is a systematized, well researched, purposive and goal-oriented course or method of action embarked upon by those ministering to the needs of the public. It is therefore in the National Policy on Education that we discern what is the government intention for higher education in Nigeria with regard to knowledge production.

The United Nations Educational, Scientific and Cultural Organization (UNESCO, 1998), defines higher education as "all types of studies training or training for research at the post-secondary level provided by Universities or other educational establishments of higher education by competent authorities. The National Policy on Education defines tertiary education (higher education) as "education given after secondary education in Universities, Colleges of Education, Polytechnics, Monotechnics including those institutions offering corresponding courses" (FRN, 2004).

The goals of tertiary education in Nigeria, as specified in the National Policy on Education are:

Contribute to national development through higher level relevant manpower training;

Develop and inculcate proper values for the survival of individual and society;

Develop the intellectual capacity of individuals to understand and appreciate their local and external environments;

Acquire both physical and intellectual skills which will enable individuals to be self-reliant and useful members of the society.

World Bank (2000) pointed out that teaching and research are the intellectual functions of higher education and are in connection with education function which incorporates cultivation of the mind, transmission of basic ideas and concepts. Nigeria has the largest university system in sub-Saharan region (38 Federal Universities, 37 States Universities and 50 private universities). There are 98 Federal and State Polytechnic/Monotechincs and 86 Colleges of Education (NUC, 2012). The figures are constantly changing as more approvals are granted to new higher institutions on a regular basis. There is therefore an abundance of evidence to suggest that public policy in Nigeria supports the position that higher education pursue the goal of knowledge production not only for its own sake but knowledge that is relevant to the nations developmental goals. As with faith, that is dead without works, policy without implementation is dead. That is why practices must be congruent with policies to yield desired outcomes. What then are the knowledge production practices in higher education in Nigeria.

\section{Higher Education Practices in Nigeria with Regard to Knowledge Production}

With regard to the production of knowledge, higher education has a production function. This implies that to produce knowledge, some critical inputs must be made and mixed or processed so that knowledge would be the outcome or end product. In Nigeria as well as in other countries these inputs are lecturers and or research fellows, money, governance (implying managerial acumen) and public policy support.

These inputs will have to be deployed in adequate proportions both in quality and quantity for the product to be of good quality. The National Policy of Education, recognizes that no education system can rise above the quality of its teachers (FRN, 2004). In the case of knowledge one can say that no knowledge produced can rise above the quality of those who produce it.

All over the world, Research and Development (R\&D) has become the basic and sustainable way of producing knowledge. What is the practice in Nigeria? According to Ogbodo, Udo, and Efanga (2009), in the first thirty years of the development of higher education in Nigeria, there was orderly and prosperous growth. The academic staff was world class. They had integrity both personal and intellectual. The system was always improving them through training and retraining in the best universities in the world.

The downward trend in public investment in education that started in the 1980s has continued till today. This has 
taken its toll on this very crucial resource input of higher education. The morale of academics as researchers has plummeted. Many of the academic that we had have migrated to foreign lands where they are more appreciated and rewarded. Those that remain have become despondent.

Today the research that goes on in universities is mainly existential. The lecturers simply do as much personal research as they can fund just for survival, for promotion. This is because strategic research that would be used to address our environmental, economic, health, industrial and social problems cannot be carried out funded from personal incomes of individuals, no matter their quality.

Money is needed, a lot of it to produce relevant knowledge. Those who must produce knowledge (egg heads) must be made comfortable, must be placed in the right conditions to thrive (incubation). They should be in "splendid isolation" so to speak, so that they could concentrate and deploy their mental powers to knowledge production.

Unfortunately, this is hardly the practice in Nigeria. The Nigerian academic at best belongs to the lower middle class. He is distracted by the uncertainties that befall the majority of Nigerians in power supply, in healthcare, in housing, in quality education for his children in his pension and gratuity. He responds therefore by frequent labour unrest and does not diligently apply himself to teaching and research.

What goes on in our higher education is not knowledge production but mainly knowledge recycling and transfer of knowledge produced by others in other systems. Our higher institutions should be the basic think tank of the society in all areas. It should continuously generate ideas and knowledge and disseminate them, develop skills and abilities in all who seek knowledge within their walls. They should be the vanguard of societal response to emergent political, economic, social and environmental problems. The advancement of mankind through the ages has been knowledge driven and knowledge should be the basic product of universities.

For our higher education to fulfill its mandate, it must devise ways of reversing the downward spiral in the quality of knowledge it produces and its relevance to the society. What then should be done?

\section{Appropriate Policy Framework for Research and Development in Nigeria}

Knowledge is a continuum and the rates of its expansion and obsolescence are so rapid that to fully take advantage or utilize knowledge as a product nation state must come up with dynamic policy frameworks that would improve the effectiveness of the knowledge continuum.

Levin (2004) identifies communities that interact in the knowledge continuum and whose interaction yield challenges that must be addressed by an appropriate knowledge based policy and practice. These communities are researchers, policy makers and practitioners. An appropriate knowledge policy therefore must have three dimensions arising from these:

Knowledge creation;

Knowledge mediation;

Knowledge application.

In Nigeria's higher education these dimensions of knowledge continuum raises important challenges that need to be addressed.

\subsection{Knowledge Creation (Production) Challenges}

The challenges raised by this on higher education are related to concerns about the relevance and quality of what is produced as well as levels of funding available for such production. In Nigeria, little new or cutting edge knowledge is produced in higher institutions, Most of what goes on is knowledge recycling or at best transfer of existing knowledge to other (students).

The funding situation for research in higher education is deplorable and this is widely known and felt. for the past decade Nigeria has consistently failed to allocate more than $10 \%$ of the budget to education. This means that the single digit allocation to education is what higher education has had to share with other levels of education in the country. When what is allocated is expressed as a percentage of Gross Domestic Product (GDP) it is even less than $3 \%$.

More than $80 \%$ of budgetary outlays for higher education in Nigeria is expanded on staff emoluments. The rest $20 \%$ goes for capital expenditure and perhaps research if anything remains. There is therefore a need for a comprehensive policy for funding research in Nigeria. This policy should highlight the important position of higher education in the production of knowledge. 


\subsection{The Knowledge Application Challenges}

The challenge here is how to strengthen the capacity of policy makers and practitioners to use research findings as basis for policy and practices. When this challenge is met, public policy will be evidence-based. Evidence-based policy is defined as "the conscientious and explicit use of current best evidence in making decisions and choosing between policy options" (OECD, 2007).

Getting policy makers and practitioners to use new knowledge as evidence is not always easy. This is because the working methods, organizational structures and public policy analysis are often not conducive to a spirit of experiment and application of new-knowledge. There is a need to develop a culture of reflection and evaluation so that research and evaluation can contribute better to innovation and improvement of practice. Furthermore, practitioners and policy makers should also be directly involved in the production of knowledge in collaboration with researchers. There is no tradition of such collaboration in Nigeria.

The relationship that is needed between policy-makers, practitioners and researcher should be like the one between theory research and practice. When consensus is achieved at all levels on the need for reflective practice and to evaluate systems and reforms, it would help create policies where outcomes would match the stated objectives.

\subsection{The Knowledge Mediation Challenges}

Mediation is the bridge between creation and application, without which successful knowledge management and use is impossible (CEC, 2007). It involves translating and disseminating knowledge and the outcomes of research through networks, websites and the media that can inform policy and practice.

In Nigeria, this appears to be the weakest link in the knowledge continuum. Where research findings exist; they are often difficult to access and to comprehend. Although the spread of the internet has led to unprecedented access to vast amounts of information, much of this is not subject to quality control. There is also the risk that irrelevant or questionable material may be taken up in the policy -making process and valuable evidence may even be lost.

There is therefore a need to develop a more efficient and effective mediation communication networks and agencies. This would make policy and practice to be better informed. When this is done knowledge production and utilization (policy and practice) would become more responsive to the needs of the society as a whole.

In advanced economics, there is a growing move from a resource-based to a knowledge-based production (OECD, 1999). In this regard many national governments have increasingly recognized "knowledge" and "innovation" as major driving forces or economic growth, social development and job creation. In this context therefore, the promotion of "knowledge transfer" has increasingly become a subject of public and economic policy. Nigeria should not be an exception.

In current innovation literature, there is an underlying assumption that there is a potential for increased collaboration between industry and universities (Argote \& Ingram, 2000). The open innovation approach to business development is explicitly based on the assumption that universities are a vital source for accessing external ideas. According to Holland (1999) universities have been deemed to be the great, largely unknown and certainly underexploited resources, contributing to the creation of wealth and economic competitiveness.

The industrial and higher education policies evidently ignore this fact. This explains the almost total absence of cooperation between industry and higher education in Nigeria in the area of knowledge production and utilization. Higher education should not only be seen as a mill for producing manpower for industry and government. It should also be seen as a veritable source of knowledge production.

In the United States of America for example, there has been a very well established and respected tradition of close mutually beneficial cooperation between the military, industry and the academic. The military/industrial complex funds ground-breaking cutting-edge research in universities and research establishments. This cooperation systematically yields new knowledge which continues to put the U.S as a leading nation in all critical areas of human development.

The government in Nigeria should come up with a national policy on knowledge creation will encourage both industry and government to engage universities and other institutions of higher education in the production and transfer of "customized knowledge" targeted to specific national and industrial problems. All progressive countries endeavor to produce knowledge that will solve their peculiar problems.

The recent move by the Federal Government in Nigeria to re-align research institutes to universities is in the right direction. That was part of the white paper on the report of presidential committee on Rationalization and 
Restructuring of the Public Service led by Mr. Steve Oronsaye. If and when implemented the research and development profits of universities would become more manifest and the knowledge production function of universities would become more established.

\section{Conclusion}

Knowledge has come to be accepted as a product and a critical resource in the creation of wealth and advancement of mankind. Every rational activity of individuals, organizations and nations has been knowledge driven. Knowledge has become the justification for everything that we do. Since knowledge is so important, its production should be given the priority that it deserves and those engaged in its production should be protected and provided for. Institutions engaged in knowledge production should be well funded.

\section{Recommendations}

Policies and practices by government and their agencies should be knowledge driven.

Government should allocate adequate funds to higher education to enable her improve the quality of her teaching and research.

Getting policy makers and practitioners use new knowledge as evidence not always easy. More awareness should be created on higher education in Nigeria.

\section{References}

Argote, L., \& Ingram, P. (2000). Knowledge transfer: A basis for competitive advantage in firms. Organizational Behaviour and Human Decision Processes, 82(1), 105-111. http://dx.doi.org/10.1006/obhd.2000.2893

Ashford, D. (1981). Policy and Politics in Britain. Oxford: Basil Blackwell.

Commission of European Communities. (2007). Towards more knowledge based policy and practice in education and training. Brussels: Commission Staff Working Document.

Dill, D. D., \& Soo, M. (2004). Transparency and quality in higher education markets. In P. Texiera, B. Jongbloed, D. Dill, \& A. Amaral (Eds), Markets in higher education: Rhetoric or reality? (pp. 61-86). Dordrecht: Kluwer.

FRN. (2004). National Policy on Education. Lagos: NERDC.

Holland, G. (1999). Forward. In H. Gray (Ed.), University and the Creation of Wealth (The Society for Research into Higher Education). Open University Press.

Ikotun, A. (2003). Concepts of public policy analysis and management: the Nigerian experience. In Maduabum Chuks (Ed.), Contemporary issues in public policy analysis in Nigeria (ASCON).

Levin, V. C. (2004). University development in Africa: the Nigerian experience Ibadan. University Press.

National Universities Commission. (2012). Summary of number, type and ownership of universities in Nigeria. Retrieved from http:///www.nuc.edu.ng/

OECD. (1999). Managing national innovation systems. Paris: OECD publication service.

Ogbodo, C. M. (2013). Issues and Trends in Nigeria Higher Education: Lagos. VITAMED Educational Books.

Ogbodo, C. M., \& Nwaoku, N. A. (2010). Quality Assurance in higher education. In P. T. Nowakowski (Ed.), Higher Education in Nigeria: Selected Aspects. U.S.A: Trafford publishers.

Ogbodo, C. M., Efanga. S. I., \& Nwokomah, J. M. (2013). Strengthening the internal quality assurance mechanism in the university. Academic Research International, 4(3), 551-558.

Organization for Economic Cooperation and Development. (2007). Evidence in education: Linking research and policy. Paris: OECD.

Stiglitz, J. E. (2000). Contribution of the economics of information to twentieth century economics. Quarterly Journal of Economics, 115(4), 1441-1478. http://dx.doi.org/10.1162/003355300555015

UNESCO. (1998). Declaration of higher education for the twenty first century: vision and action. World conference on Higher Education, $9^{\text {th }}$ October. Retrieved from http://www.unesco.og/education/educprog/wche/declarationeng.htm

World Bank. (2000). World Development indicators. Washington D.C.: The World Bank. 


\section{Copyrights}

Copyright for this article is retained by the author(s), with first publication rights granted to the journal.

This is an open-access article distributed under the terms and conditions of the Creative Commons Attribution license (http://creativecommons.org/licenses/by/3.0/). 